\title{
Encuesta sobre la reforma sindical española
}

\begin{abstract}
REVISTA DE FOMENTO SOCIAL, ha querido realizar un sondeo de opinión sobre la reforma sindical, planteando catorce pregun* tas sobre las cuestiones más difíciles y debatidas en la materia a un grupo de personas significativas, por uno u otro motivo, en la actual fermentación de ideas y proyectos sindicales en nuestro país. Ofrecemos a continuación el cuestionario, así como las respuestas recibidas, representativas de otras tantas ideologías y actitudes político-sindicales. Nuestro breve comentario lo podrá encontrar el lector en el artículo "Editorialn de este mismo número de la Plevista.
\end{abstract}

\section{CUESTIONARIO}

1. ¿Organización sindical unitaria o actuación unitaria, dentro de un plurallsmo organizativo? ¿Por qué?

2. ¿Libertad de asociación sindical ya, con reconocimiento jurídico de las actuales organizaciones ilegales U.G.T., U.S.O., CC.OO., C.N.T., S.T.V., S.O.C., etc., y de otras que se pudieran formar? ¿Por criterios de acción politica o por cuestión de principio?

3. Si es usted partidario del principio de libertad sindical, ¿cómo comm paginarlo cen la conveniente actuación unitaria del movimiento obrero? ¿Cómo hacer esta última viable, operativa?

4. ¿Es usted partidario, en principio, de la independencia de las organizaciones o centrales sindicales respecto de los partidos políticos?

5. ¿Piensa que buscar tal independencia, en la práctica, es una pura utopia? ¿Por qué?

6. En caso de que lo considere conveniente, ¿cómo salvaguardar en la práctica tal independencia o cómo paliar, al menos, sus efectos, si la considera utópica? 
7. ¿No opina que los sindicatos obreros, cuando adquieren poder, tienden a actuar como grupos de presión que someten a sus propios intereses los generales del país? Piénsese en ltalia, en inglaterra...

8. Para evitar estos conflictos y desorden de intereses, ¿considera necesario un pacto soeial entre los Gobiemos representativos y las organizaciones sindicales?

9. El pacto social ¿no supone una bipolaridad del poder político, compar. tido entre el Gobierno y los sindicatos? ¿No deberian entrar, entonces, las organizaciones sindicales en los propios mecanismos democráticos de elección política?

10. ¿Cómo concibe el sindicalismo? ¿Reivindicativo, pero dentro del modelo de sociedad europeonoccidental? ¿Revolucionario, en el sentido de aspi. rar al cambio o superación del modelo? ¿Cuáles serían, en este útimo caso, los rasgos fundamentales, ho utópicos, de esa sociedad futura?

11. En cuanto a democracia sindical, ipiensa que soler, a través de las elecciones, debe estar en la base, en los trabajadores afliados, o más bien debe dimanar y ejercerse desde la instancia y dirección superior de un partido? ¿Por quê?

12. ¿Qué destino habria que dar, en su opinión, al actual patrimonio de bienes de la Organización Sindical española?

13. ¿Cómo vería usted el encuadramiento y el futuro de las obras sindicales actuales, como Obra Sindical de Cooperación. Servicio Sindical de Estadística, Crédito y Caución. Grupos Sindicales de Explotación en Común, Obra Sindical del Hogar, Obra Sindical de Artesanía, Escuelas Sindicales de Formación Profesional, Instituciones Sindicales de Previsión?

14. En un sistema de libertad sindical, con reconocimiento legal del derecho de huelga, ¿tendifa sentido y justificación para usted la actual legislación restrictiva del despido? ¿No quedaría superada como algo incoherente y contradictorio?

\section{RES UESTAS}

DORADO ZAMORANO, Roberto. Alliado al grupo sindical U. G. T. y al politico P.S. O. E. Contesta a la encuesta a título personal.

1. Una organización sindical unitaria, descle luego, pero tras un proceso de clarificación previo. De lo contrario, si no existe un tiempo de contraste, de crítica, de identificación, la organización sindical unitaria puede ser un fraude hermosamente bien presentado, pero un gran fraude. Más vale ir paso a paso, sin precipitaciones, hacia la unidad a través de la acción común, que luego dar marcha atrás por haber ido demasiado de prisa en una acción puramente voluntarista.

2. La libertad es un principio ciue no puede ser objeto de discusión. Existe o no libertad de asociación; si existe, cualquier trabajador debe ser libre 
para asociarse con otros para defender sus intereses. El derecho a la libre sindicación, además de un principio es, por serlo, un punto de ruptura con el sistema dictatorial residual aún vigente, por lo que no puede ser objeto de transacción alguna, como algunos han estado tentados de hacer.

3. La libertad sindical no está en contradicción con una actuación unitaria del movimiento obrero, salvo que alguien crea tener por sí solo la "verdad proletarian e intente imponerla a los demás. La unidad de acción democrática es viable dentro de la libertad sindical, incluso la convergencia en una estructura común que preserve las actuales organizaciones como tendencias, siempre que asegure el derecho a éstas o a cualesquiera que se pueden formar, a separarse cuando lo crean oportuno. Como la indisolubilidad matrimonial es un atentado a la libertad de los cónyuges, la unidad para siempre y por decreto podría ser otro atentado a la libertad de asocian ción y a la libertad individual de los trabajadores.

4 y 5. Se puede ser independiente respecto de algo o alguien con quien nada se tiene que ver. Pretender separar lo sindical de lo politico, o viceversa, es hipocresia, ingenuidad idealista o un planteamiento reaccionario. Aunque existen esferas netamente politicas y netamente sindicales, ambas se solapan $y$, en cualquier caso, mantienen una dialéctica permenente. No hay lugar. a mi modo de ver, para la independencia, lo cual no implica que no pueda existir autonomía de ambas. Lo politico y lo sindical se influyen mutuamente, sin perjuicio de mantener su propia identidad. La autonomia no es una artimaña que esconda, para los que piensan como yo, la vieja y desprestigiada tesis de la correa de transmisión, sino la solución correcta a dicha interdependencia entre la dimensión política y la sindical.

6. La autonomía se salvaguarda precisamente aceptando la interrelación y siendo conscientes de ella, no metiendo la cabeza debajo del ala o ha. ciéndosela meter a los demás. La autonomía se preserva con unos sindicatos auténticamente democráticos, donde sus afiliados, sin distinción de su posible militancia política, puedan opinar y elegir a sus representantes en congresos, can garantías y transparencia, no por cooptación, y donde los derechos y deberes de éstos estén claramente definidos en unos estatutos.

7. Los sindicatos son grupos de presión y están conceptuados como tales en sociología. Lo son, de igual modo, las patronales. Pero cuando un sindi. cato tiene algo más que una actitud reivindicativa a corto plazo, es más que un grupo de presión, es una fuerza capaz de transformar la sociedad. Los ejemplos que ofrecen ustedes, especialmente el inglés, parece que, momentáneamente, en esos lugares se ha desvanecido la dimensión revolucionaria, por lo que actúan con la perspectiva alicorta propia de un grupo de presión integrado en el sistema, y su comportamiento en algunas ocasiones es con servador y corporativo. Esta critica, a vuela pluma, es arriesgada, porque no hay lugar para explicar, por otra parte, las grandes aportaciones de estos sindicatos, ni a efectuar un analisis de por qué se encuentran en esta situación de "impasse" provisional.

8. El pacto social puede ser en un momento dado de la historia de un país una solución, pero siempre una solución transitoria. De no ser así, el sindicalismo se convertiria en un sindicalismo pesetero, sin capacidad de respuesta y de solución superadora de la sociedad capitalista.

10. Por mis anteriores respuestas está claro que no propugno un sìndicato meramente reivindicativo, aunque este aspecto sea imprescindible, 
tanto más cuanto que no tiene que estar en contradicción con un plantea miento de transformación de la sociedad. Un sindicato socialista y demo. crático debe evitar tanto las actitudes aventuristas y seudorrevolucionarias como el conformismo de anclarse en el regateo exclusivo de un salario. por importante que éste sea, como lo es a corto plazo.

Pretender hacer futurología es siempre temerario y más cuando uno piensa que son las clases sociales las que conforman el presente y el futuro. Sin embargo, pienso que hay que ir a una sociedad que elimine la propiedad privada de los medios de producción, que descentralice los centros de poder, que luche contra el burocratismo sin caer en un vacío de autoridad, que procure superar la contradicción entre administradores y administrados; en definitiva, una sociedad libre y humana, lo que en estos tiempos se ha vulgarizado como una sociedad socialista autogestionaria.

12. El patrimonio de la Organización Sindical, previa la devolución de lo incautado a la U.G.T. y C.N.T., debe devolverse a todas las confedera ciones, incluidas las anteriores, o bien repartiéndole proporcionalmente a su importancia e implantación, o bien mediante la creación de servicios unitarios dirigidos por todas las organizaciones con igual criterio de proporcionalidad.

14. La libertad sindical supone; al mismo tiempo, libertad para la libre asociación de los patronos para defender sus intereses. No veo por qué han de unirse libertad sindical y reconocimiento del derecho de huelga con la libertad de despido. El derecho al trabajo no puede quedar sometido al interés particular y egoísta de un patrono. No se puede aceptar la libertad de despido, lo cual no significa que no existan ocasiones en que se deba proceder a la reestructuración de las plantillas para la modernización y racionalización de una empresa o un sector industrial. En este caso, los trabajadores, si controlan el proceso de reestructuración, si existe un seguro de paro digno, si existe una enseñanza adecuada para su reconversión y no se deja al arbitrio del patrono, no se opondrán a ello. Si no es en esas condiciones, la libertad de despido supondría el paro, y el paro no es pactable, pues atenta al derecho inalienable al trabajo, al tiempo que es un arma del capital para regular el mercado de trabajo a su conveniencia.

18 de octubre de 1976.

ELORfIAGA, Gabriel. De Reforma Democrática. Contesta a titulo personal.

1. No entiendo la pregunta. Lo que más interese a la base.

2. No entiendo la distinción entre "acción politica" y "cuestión de principios". Libertad de asociación sindical, simplemente, como parte de una concepción democrática de la convivencia.

3. La libertad sindical es la verdadera libertad sindical, y el umovimiento obreron más parece una referencia retórica del totalitarismo.

4. Naturalmente.

5. No. Lo que sucede es que el ámbito sindical, como cualquier otro, nunca será absolutamente aséptico y siempre habrá tendencias políticas más 
favorables a las reivindicaciones sindicales y otras menos, y, como es lógico, existirán relaciones entre lo sindical y lo político, pero estas relaciones to deseable es que sean por la vía de los acuerdos entre partes libres, pero sin subordinación ni dependencia incondicional del sindicalismo de unos patronos ideológico-políticos de una "nueva clase" partidista.

6. Tal independencia tiene que ser una consecuencia de la autenticidad democrática de las asociaciones sindicales.

7. Sí. Pero no veo razón alguna por la que no tengan derecho a actuar como grupo de presión los sindicatos, cuando también, en las mismas circunstancias, actúa como grupo de presión la Banca, las multinacionales y otros grupos e instituciones. Por otra parte, no está claro que los intereses sindicales tengan, necesariamente, que ser contrarios a los intereses generales del país. Lo más frecuente es que los intereses del pueblo sean coincidentes con la prosperidad del país, saivo circunstancias de ofuscación.

8. Debe haber un pacto social entre la empresa y el trabajo. Los gobiernos pueden ser árbitros, nunca parte del pacto social, pues el gobierno no es un sector de la sociedad, sino un instrumento de administración y política al servicio de todas las partes.

9. El pacto social, si es "socialn, no es un pacto político. El poder de los gobiernos se comparte con el pueblo, del que emana democráticamente, en su totalidad y no puede enajenarse con cada una de las partes. El gobierno se debe a la voluntad general y, por supuesto, las organizaciones sindicales tienen su propia capacidad para influir en la configuración de esa voluntad general democráticamente expresada.

10. El sindicalismo reivindicativo es el único sindicalismo. El Ilamado sindicalismo revolucionario no es otra cosa que un frente político de determinada ideología, en su etapa de lucha por el poder político, y una vez instalada esa ideología suele convertirse en una burocracia dócil al sistema establecido, sin capacidad alguna de autonomía para la lucha cotidiana por los intereses auténticamente sindicales.

11. Debe estar en la base, y no creo que sea necesario explicar por qué. porque el sindicato debe ser de los trabajadores y de nadie más.

12. Es un asunto complejo, dado que se ha formado con aportaciones de una cuota sindical general $y$, además, de empresarios y trabajadores. Por tanto, no sería equitativo dárselo a una parte o sector. Creo que lo razonable es que se constituya en un ente autónomo, del que puedan beneficiarse todos, y que en su gobierno pueda darse un tipo de administración proporcional y representativa.

\section{En una dirección similar a lo dicho con el patrimonio sindical.}

14. Efectivamente existe cierta contradicción. Por otra parte, el tema del despido es socialmente tan grave y delicado, más en momentos en que existe un porcentaje de paro de cierta envergadura, que no me atrevería a propo. ner el libre despido como una tesis aceptable. Creo que la necesaria productividad y disciplina en el trabajo debe lograrse por algún camino y con una mayor agilidad en la contratación, pero entiendo que habria que crear fórmulas adecuadas que impidiesen toda utilización abusiva del poder del emplea- 
dor, a la vez que la picaresca a que da lugar la inamovilidad de malos trabajadores. Creo que es un campo de elaboración de Derecho del Trabajo en el que no puede ni improvisarse ni dejarse llevar de simplismos y en el que los valores humanos deben tenerse en cuenta, ante todo. Pero estoy de acuerdo en que hay algo que perfeccionar o reajustar en este asunto para mejorar la coherencia de la relación empresa-trabajo, sin traicionar a los trabajadores.

23 de septiembre de 1976.

GARCIA SALVE, Francisco. Del Secratariado de la Coordinación General de Comisiones Obreras (CC.OO). Contesta reflejando de hecho las udeas de cC. 0 o.

1. Comisiones Obreras está por la organización sindical unitarla libremente adrnitida por la clase obrera. Ha sido y seguirá siendo una lucha constante de $\mathrm{CC} . \mathrm{OO}$, el conseguir un sindicato unitario que abarque a todos los trabajadores, porque creemos que la clase obrera quiere esta unidad, porque es vital esta unidad para luchar eficazmente por los intereses sociopoliticos del proletariado, porque las distintas ideologías politicas en que legitimamente pueda militar el trabajador no es impedimento para la unidad dentro de un solo sindicato. Claro está que Comisiones Obreras, como un mal menor, admitirá la actuación unitaria dentro de la pluralidad, si ésta se diese. Pero no queremos la pluralidad porque la triste experiencia histórica, por un lado, nos habla claro de los enfrentamientos dentro de la misma clase obrera, $y$, por otro lado, es evidente que la existencia de un sindicato unitario no significa imposibilidad absoluta, aunque tenga sus dificultades, sino grandes ventajas. De cualquier forma, ya de arranque lo digo, Comisiones Obreras respetará la voluntad mayoritaria de la clase obrera, que es la única legitimada para disponer libremente de sus destinos sindicales. Comisiones Obreras ltama a todos los trabajadores a un Congreso Sindical Constituyente, cuando se conquiste la libertad sindical.

2. Pedimos la libertad sindical sin más aditamentos. Porque es derecho inalienable de los trabajadores. Ni leyes sindicales, ni reconocimientos jurín dicos de nadie ni de nada. La legitimidad sindical viene de abajo, y son los trabajadores quienes tienen que marcarla. Libertad sindical como primer paso para ir hacia ese Congreso Sindical Constituyente, en el cual, previa una etapa breve de mentalización, asambleas masivas y elección desde la base en las empresas, se decidan las lineas del futuro sindicato que queremos. Comisiones Obreras quiere que sea la clase obrera la que marque sus caminos, por eso el Congreso Sindical Constituyente será necesario inmediatamente después de la libertad sindical y con la colaboración de todas las organizaciones sindicales que existen. Como se ve, es una cuestión de principios.

3. La "conveniente actuación unitaria" es algo necesario, esencial, pero como un minimo indispensable en la lucha sindical. Como un mínimo y no como una meta: suprema del sindicalismo. En la pregunta hay implícita una equivocación; parece presuponer que los partidarios de la libertad sindical propugnamos por eso la pluralidad. Es fundamental comprender que la libertad sindical no implica la pluralidad. Comisiones Obreras quiere, de fiende, un sindicato unitario libremente elegido por los trabajadores, de libre 
afiliación. Si se diese pluralidad sindical, ¿cómo hacer viable la conveniente actuación unitaria? Por medio de un organismo de coordinación, donde estén representados los distintos sindicatos. Pero insisto que sería un mal menor. Es preferible marchar unitariamente en un sindicato, con las dificultades inherentes a las diversas tendencias; preferible, digo, que la pluralidad sindical con esta mínima unidad de acción.

4. Totalmente partidario. Como principio. El viejo estilo de los sindicatos como correa de transmisión de los partidos hoy está desfasado y se muestra pernicioso, porque provoca la pluralidad, crea la división dentro de la clase obrera y traslada los problemas de partido al campo sindical. En la práctica se reduce a una duplicidad innecesaria de organismos: los mismos miembros en los organismos políticos y en los sindicales. Duplicidad de afiliación.

5. No es utopia, porque el hecho de que sea difícil su realización no significa que sea imposible. En un sindicato unitario, donde tengan cabida las distintas ideologías, los hombres más mentalizados serán los más interesados en conservar la independencia de los partidos como punto esencial para conservar la unidad sindical, que es vital.

6. Para salvaguardar la independencia habrá que estructurar los órganos de dirección por representación proporcional de las distintas tendenclas, y las decisiones se tomarán por mayoría cualificada. Pero los mil detalles estructurales que hagan posible la democracia obrera y no rompan la unidad serán concretados en la elaboración de los estatutos de la Central Sindical Unitaria.

7. Creo que tienden a actuar como grupos de presión que exigen los derechos de la clase obrera. En una sociedad capitalista, como en Itaila, Inglaterra, etc., son las multinacionales las que real y despóticamente están sometiendo los intereses del país a los intereses propios de su internacional explotación. Es evidente, por ejemplo, que a la I.T.T. nunca le han interesado los intereses generales del país, sino sus propios y exclusivos beneficios. Si el proletariado es internacional por sentido de clase oprimida, el capitan lismo no tiene más patria ni más interés que su beneficio opresor, La histo. ria es larga y fecunda en ejemplos, piénsese en Alemania, Francia, Holanda, etcétera, en todos los paises capitalistas donde el beneficio manda y por el beneficio se ha esclavizado a los pueblos. Los sindicatos obreros luchan por contrarrestar esta impune y terrible explotación.

8. ¿El pacto social entre los gobiernos representativos (¿de quién?) y las organizaciones sindicales? Cuando los gobiernos representan a una mi. noría de capitalistas y defienden sus exclusivos intereses, el pacto social es un suicidio para la clase obrera, que, de momento, sólo pide sus más elementales derechos que se le niegan. El pacto social en nuestro pais, donde la aguda crisis económica está agudizada por una inseguridad política que provoca, principalmente, fuga de capital alarmante y huelga de inversiones; una crisis económica de la cual la clase obrera no es responsable, porque siempre se la ha mantenido injustamente alejada de los órganos de direc. ción, donde la clase obrera no tiene ninguna posibilidad de control de beneficios de capital; en este panorama, el pacto social es un absurdo además de una ingenuidad. Hablar de pacto social a nuestros trabajadores, que no ganan ni el mínimo vital, con un paro de más de un millón y de los cuales muy pocos cobran subsidio de paro y los que lo cobran es una miseria... 
Pacto social entre la organización sindical que representase a los trabajadores $y$ un gobierno que si a alguien representa hoy es a las fuerzas posfranquistas y continuistas, visto desde mi ladera de proletario, es para la sonrisa. La clase obrera es honrada, pero no tonta.

9. De hecho, aqui, no supone esa bipolaridad que no existe. El poder político está hoy en España en manos del capital, casi diria que en manos de la gran Banca. En la Central Sindical Unitaria que Comisiones Obreras propugna, cada uno de sus afiliados daria su voto al partido que cada cual considerase que mejor defiende los intereses de la clase obrera, con plena libertad.

El sindicato unitario e independiente, sin ser apolitico, no tiene misión política como tal. Hay partidos de clase obrera que son los llamados a la gestión del poder.

10. Nuestro sindicalismo de nuevo tipo, el que Comisiones Obreras propugna, será de finalidad socio-politica. No meramente reivindicativo, porque todos sabemos que las subidas salariales y otros beneficios puramente reivindicativos son absorbidos de mil modos por una sociedad capitalista, son absorbidos si no se consiguen reivindicaciones politicas: las libertades democráticas esenciales. Es revolucionario en el sentido de cambiar la sociedad y terminar con la explotación del hombre por el hombre. Pero una revolución que surja desde las masas, por la asamblea obrera, que será la médula del nuevo sindicalismo. ¿Cómo alargarme en pergeñar los rasgos fundamentales de la sociedad futura? ¿No seria una evasión, un modo de no hacer frente a los problemas de hoy? Por lo demás, me exigiria ser muy largo para ser exacto.

11. La democracia interna sindical debe estar en la base, en los trabajadores afiliados e incluso, pensamos, en los no afiliados, cuando la asamblea sea elegida por representantes de fábrica, empresa o tajo. Si el sindicato es totalmente independiente de los partidos, la pregunta en la segunda parte resulta superflua.

12. El actual patrimonio de la actual $O$.S. verticalista pertenece en exclusiva a todos los trabajadores, porque hemos sido todos los trabajadores y sólo los trabajadores los que hemos cotizado obligatoriamente. Incluso la cantidad que cotizaba la patronal por cada trabajador nos pertenece, porque no fue sino el salario diferido. Es evidente que nadie paga nada por un asalariado si no se lo saca al propio asalariado. Por eso, todo el patrimonio sindical debe pasar integro en propiedad a todos los trabajadores. Con el sindicato unitario no habria gran dificultad. Con la pluralidad sindical habrá que estructurar un organismo unitario de los trabajadores que administre ese patrimonio. El intento de hacer al gobierno propietario de este patrimonio es una solución falsa.

13. Podrían ser asimiladas, estructuradas y algunas eliminadas fpor inútiles y burocráticas) por el sindicato unitario de todos y al servicio de toda la clase obrera.

14. El derecho al trabajo de todo ciudadano es algo que está por encima del derecho al despido, impuesto, de hecho, por los intereses de la explotación capitalista. El despido libre, de hecho, ha estado funcionando y sigue en nuestro pais. Los despidos de Telefónica pueden ser un ejemplo signifj- 
cativo reciente. Una sociedad capitalista que amontona beneficios está viciada de raíz, y mientras exista habrá contradicciones, fruto de los egoísmos del capital, que es, esencialmente, explotador porque busca la ganancia por encima de todo. El despido libre en los paises capitalistas democráticos es el arma que tiene el capital para defender sus privilegios. Si en los paises capitalistas está latente la dictadura, empleará además la represión policiaca y hasta la judicial como arma de su explotación, como sigue sucediendo todavía en España. Una sociedad que margina en el paro a la clase obrera es una sociedad con cáncer. Y la clase obrera se defiende con la huelga, como un derecho extremo, pero inalienable, contra la explotación del capital. El capital, que domina, que está en el gobierno, defiende sus privilegios con uñas y dientes, ya lo estamos viendo.

Sólo un gobierno democrático del pueblo dếenderá los derechos del pueblo. Mientras, todo serán parches. Como se ve, de fondo está latente toda la corrupción que supone que los medios de producción estén en manos de unos particulares para su personal interés. Mientras persista esta con rupción, la clase obrera, la clase explotada, se defenderá a la medida de sus posibilidades con la unidad sindical como base.

23 de septiembre de 1976.

GARCIA RUA, José Luis. Afiliado al grupo sindical Confederación Nacional del Trabajo (C. N.T.). Contesta a título personal, ssin encargo ni man dato de la Organización, pero creyendo reflejar en su esencia el espiritu libertario que la animan.

1. Desde luego, en las circunstancias actuales, es, más que preferible, necesaria la actuación unitaria dentro de un pluralismo organizativo, y aun esta actuación unitaria debe ser concebida en el seno de la allanza obrera, es decir, no debe ser de ninguna manera mecánica, sino debatida, matizada y aprobada en el seno de las secciones de los sindicatos, nunca producto de un acuerdo burocrático de cúspide. Las razones pueden ser unas de tipo general y otras de tipo circunstancial. Entre las de tipo general puede contarse el hecho de que, habiendo diversificación política, es imposible que ésta deje de reflejarse en el seno de la vida sindical. Una unidad en estas circunstancias sólo podria lograrse a costa de reducir la lucha sindical a un papel de comparsa subsidiario, puramente economicista, peligrosamente reformizante y al margen de todo proyecto finalista, ya que éste, por representar tun nivel estratégico, sería concebido de manera diferente por los diferentes grupos, asi como serían concebidos de manera igualmente diferente los pasos tácticos orgánicos que corresponderian a diferentes estrategias. Es saludable, por tanto, y más que saludable, necesario, un determinado grado de competencia sindical que vivifique las acciones de los trabajadores como una vía autónoma y no subsidiaria y que las haga trascender los estrechos límites de la negociación burocrática, así como el mecánico papel de correa de transmisión de los partidos políticos. Debe ser aleccionador el caso de Italia, donde, después de la guerra, en el 45 , se parte de una unidad sindical ficticia, que inevitablemente habria de fracasar por las igualmente inevitables incidencias políticas, hasta la situación actual, en la que, desde la pluralidad, se tiende ya a una unidad de acción más consciente, más pro. funda y de mayor alcance, por ser el resultado de la acción de las bases obreras, que tienden a superar la dialéctica de los partidos. O el caso de 
Alemanía, donde, en efecto, a traves de la D.G.B., se consigue una unidad sindical, pero es a costa de constituirla en una central eminentemente buro crática y reformista, en gran medida responsable de la integración del proletariado alemán en el sistema capitalista burgués. Entre las razones de tipo circunstancial, se puede contar el hecho de que, después de cuaren. ta años de dictadura, amplisimos sectores de la clase trabajadora carecen de una información y una concienciación apropiada, y en estas circunstancias pueden ser fácilmente embaucados por cualquier programa integrador de sociedad de consumo, y por eso necesitan, más que nunca, de las centrales sindicales que actúen en su seno a modo de plataformas de formación, al objeto de despertar crecientemente en el seno de las grandes masas el sentido del destino de la clase trabajadora.

2. Desde luego es necesario el reconocimiento juridico de las centrales sindicales, que no sería sino el reconocimiento de derecho de lo que es ya un hecho de la clase trabajadora. Connciden aquí la acción política y la cuestión de principio. Por principio, en una democracia, debe haber libertades de asociación, y entre ellas la sindical. Pero, por otro lado, sería políticamente clego no reconocer un fenómeno práctico y significativamente operante en el seno de la sociedad.

3. Como queda dicho más arriba, las necesidades unitarias se deben cumplir en el seno de la alianza obrera establecida en el seno de las asambleas, donde cada grupo sindical debe defender sus opciones. Son estos acuerdos los que deben canalizarse a través de los cauces orgánicos sindicales; que de esta manera se justifican también como cenales de agilización del movimiento asambleístico. Asi se justifica también la democracia inter. na, no en abstracto-como sería la otorgación de una pretendida función sin órgano para la misma-, sino real, desde el momento en que hay unos instrumentos organizativos hábiles para hacer eficaz la opinión del grupo.

4. Las centrales sindicales deberian ser independientes de los partidos politicos. Es más, podria decirse que una centrá sindical lo es tanto más cuanto más independiente es de un partido, y que la auténtica central sindical no debe tener relación ninguna con partido politico. De esta manera, la certral sindical como organización autónoma de clase, puede plantearse por sí misma proyectos finalistas propios, sin necesidad de generarlos como apéndices de otros proyectos superiores elaborados fuera del sindicato.

5 y 6. Si es el caso de centrales relacionadas con partidos, desde luego, en un grado u otro, dependen de los mismos, siendo más fuerte la dependencia cuando el partido determinante sea más centralista y autoritario, y menor cuando el partido correspondiente se distingue por una mayor democracia y descentralización. A pesar de todo, siempre es deseable y se puede mantener una lucha interna en toda central sindical por conseguir una mayor independencia con relación al partido politico, y, desde luego, una de las formas de conseguirlo, o al menos de paliar los efectos de la dependencia, es prohibir la doble representación. El militante debe optar entre la vía sindical y la vía politica, y si elige la vía sindical, debe pensar que en ella tiene que representar también a hombres de ideologías diferentes de la suya y a los cuales debe fidelidad sindical, que no debe ser traiclonada por imperativos de su partido.

7. Un auténtico sindicato debe ser un sindicato de clase y por lo tanto debe luchar siempre por los intereses de la clase trabajadora. La pregunta, 
tal como está planteada, sólo sería contestable pensando que pudiera haber reivindicaciones obreras que se volvieran contra la propia clase obrera. Pero ésta siempre actúa con gran sentido de la realidad, y, por supuesto, dentro de un sistema capitalista no tiene interés ninguno en destruir la industria en la que trabaja y de la que saca el jornal para su sustento. Pero la clase obrera no está dispuesta a cue se cargue en su cuenta todo el superconsumo y la sobreacumulación de la clase burguesa. Otra cosa es que, en determinadas circunstancias, la clase obrera se plantee, en un momento de crisis, un cambio de las relaciones de producción, lo cual no supondría-sino todo lo contrario-ir en contra de los intereses generales.

8. Los gobiernos, para. serlo, tienen siempre que estar enmarcados en un Estado y representar o seguir los principios generales del mismo. Ahora bien, un Estado sólo en una interpretación hegeliana representa los intereses generales de una comunidad nacional. En realidad, un Estado constituye siempre el conjunto de aparatos, instituciones y medios aptos para la defensa, mantenimiento y promoción de los intereses de la clase dominante, que define las líneas generales de la convivencia en provecho propio, natural. mente. En consecuencia, los gobiernos, como portavoces del Estado, no pueden constituirse en árbitros imparciales en las luchas del capital y ef trabajo. Los contenciosos entre éstos sólo pueden dirimirse directamente por una correlación de fuerzas, entre las que cuentan, naturalmente, las cir cunstancias y la coyuntura. Como partimos del hecho de que la clase obrera no es suicida, no va a producir por sí misma situaciones de las que se deriven su destrucción o su menoscabo, pero tampoco va a permitir que nadie, a socaire de una imparcialidad, falsa en el fondo, determine los techos de sus reclamaciones, sino que se arroga ella misma la racionalidad de decidir, según sus intereses, el cuánto, el cuándo y el cómo de sus reivindicaciones. No hay, pues, más acuerdo que el que las circunstancias reales reconocidas por la clase trabajadora, y no las instancias politicas, impongan en cada caso.

9. No puede existir bipolaridad de poder político compartido entre el gobierno y los sindicatos. Los sindicatos no juegan, por principio, al juego político. El único reflejo político de los sindicatos será el que se derive del hecho de que algunos de estos partidos son correa de transmisión de partidos politicos, a los que sirven en forma de presión o de masas electorales. Pero esto es otra historia, y para nosotros constituye una desviación del sindicalismo. El auténtico sindicalismo debe ofrecer una estructura orgá. nica de democracia directa, asambleística, no representativa. Sus delegados deben ser puros ejecutores de acuerdos de base. Ahora bien, este tipo de metodología democrática directa no se compadece en absoluto con la metodología de la democracia formal representativa, que es la típica de la politica burguesa. Por lo tanto, el auténtico sindicalismo no es que no quiera jugar al juego político parlamentario burgués, es que no puede jugario, por" que, en el instante en que se adaptara a la metodología democrática-formalrepresentativa, cesaría de ser un sindicato donde las bases (porque no hay cúspides) son siempre las que deciden. Por eso las formaciones sindicales se apartan tanto más de su destino de instrumento directo de la clase obrera cuanto más copian en su estructura orgánica la estructura de un partido político.

10. El sindicato puramente reivindicativo dentro de los esquemas capitalistas es un sindicato reformista que cumple la misión de integrar al proletariado en la sociedad burguesa. Es, pues, un instrumento de la burquesía. El sindicato auténtico de clase debe contener en su práctica un finalismo revolucionario que aspira a constituir la sociedad presente en una sociedad 
de iguales, en términos de realidad y no de formalidad. Los rasgos fundamentales de esa nueva sociedad sexán los de una sociedad sin clases, en la que todos trabajen, salvo los incapacitados, y en la que todo el mundo tenga su puesto asegurado, libre de toda competencia. Será una sociedad autogestionada en todos sus términos, en la que, finalmente, el gobierno de las personas haya sido sustituido por la administración de las cosas, y en la que la misma administración será cosa de los administrados. Será, finalmente, una sociedad en la que el principio de subordinación (= autoridad) haya sido sustituido por el principio de coordinación (= democracia directa, eficaz y científica), y para la cual, partiendo de la racionalidad participativa de todos los individuos y comunidades, se propone, programáticamente y por libre incorporación, un organigrama coordinativo de tres grandes líneas verticales paralelas de autoorganización: la que asegura el funcionamiento del circuito económico en el triple aspecto de producción, distribución y planificación y que está representada por la arquitectura de todas las federaciones de industria y ramos de producción, con base en los Consejos Obreros y cuya célula básica última es la asamblea de empresa; la que representa tha arquitectura similar con base en los consejos de vecinos, ascendente por los consejos municipales, comarcales, regionales, etc., que asume la tarea de la autogestión administrativa, y cuya célula básica última es el comité de barrio; y, finaimente, la que representa el encuentro y coordinación de ambas realidades sociales en su función ascendente, y donde por la confluencia de todos los datos de la realidad, a nivel local, comarcal, regional, etc., se estará en disposición de proponer medidas de alcance más general, o sea, de hacer visible la compatibilidad o incompatibilidad de los acuerdos tomados por separado en las dos primeras arquitecturas. La célula básica de esta tercera línea serian los Consejos Generales, y estarían constituidos por miembros elegidos de los Consejos obreros y de Vecinos, res. pectivamente, locales, comarcales, regionales, etc. Estas tres grandes líneas de organización de las necesidades básicas estarían atravesadas por múltiples líneas asociativas horizontales significativas de los sindicatos o Consejos Unicos, así como de otras asociaciones comunitarias en las que se canalizase la vida solidaria total de los grupos sociales respectivos, por encima de todo compartimento estanco profesional o de dedicación especializada. Esta espontaneidad y vitalidad social, solidaria en los niveles horizontales con sus facultades de decisión, sería constantemente el factor de corrección inmediata de cualquier posible tendencia burocratizante que apuntara en los niveles de coordinación vertical. Dentro de esta estructura y siempre sobre el respeto básico a los canales de conducción y operatividad social estam blecidos, regirán una serie de principios fundamentales, tales como soberania de asamblea, democracia directa de ejecutores de mandatos asambleisticos, superación de toda norma ideológica con carácter dominante y apriorístico o con otra nomenclatura, libertad de pensamiento y expresión, libertad de asociación, respeto fundamental de cualquier forma de expresión espontânea que no sea objetiva y flagrantemente lesiva de la libertad de los otros.

11. Despues de todo lo dicho queda suficientemente contestada esta pregunta.

12 y 13. Partiendo del hecho de que reconocemos como lo más correcto y real, en las circunstancias actuales, el pluralismo sindical, o sea, la identidad organizativa, complementado por la Alianza Obrera, estimamos que, después de devueltos los bienes obreros a las organizaciones primitivas que los poseían con anterioridad a los años 36 ó 39 , se debe proceder con, el resto de los bienes de la $O . S$. producidos por las cotizaciones obreras desde 1939, de la siguiente manera: Reconocido que el pluralismo sindical 
es hoy, más que beneficioso, una necesidad de la clase trabajadora, se deben repartir equitativamente, entre todas las centrales sindicales, todos los bienes repartibles de la O.S. verticalista a fin de que cada central sindical pueda llevar a cabo con mayor eficacia y efectividad su tarea de organización, instrucción y potenciación de la clase obrera. Respecto a aquellos otros bienes que, por su carácter, no sean repartibles, se deben, en cada localidad y en cada caso, constituir comités de administración mancomunada de la Alianza Obrera en beneficio de toda la clase obrera en general, sobre la base de que ninguna organización específica pretenda capitalizar, propagandisticamente y en su propio beneficio, los frutos de esta administración. Estos comités de administración mancomunada de la Alianza Obrera tendrán la virtud, aparte los otros acuerdos unitarios de lucha que se provean, de establecer bases de afianzamiento de la confianza entre la militancia de las diferentes centrales sindicales, producir el hábito del trabajo mutuo democrático y estrechar los lazos sindicalistas, camino de una auténtica Confederación desde las bases militantes. Esto es lo que se pro pondría para las entidades enumeradas en el punto 13 y se puede hacer extensible a la forma del control obrero de la Seguridad Social.

14. No tiene nada que ver el impedimento del despido libre con el derecho de huelga. Jurídicamente, las relaciones de trabajador y patrono están reguladas por un contrato, y en ese contrato, como un derecho más del trabajador, debe estar incluido el derecho de huelga, lo mismo que el derecho a instalaciones higiénicas, tiempo de bocadillo, seguridad en el trabajo, etc, de manera que practicar la huelga en estas condiciones no es hacer nada ilegal $y$, por lo tanto; no es atentar contra el contrato que liga al patrono y al trabajador, y si no hay atentado contra el contrato, al patrono no puede rescindirlo pura y simplemente de una manera unilateral y caprichosa y sólo subjetivamente justificada, según es norma usual en cualquier ordenación jurídica. La único que jurídicamente le cabria al patrono sería sustituir ese contrato por otra forma de contrato, para lo cual tendria que entrar en negociación directa con el propio trabajador.

10 de octubre de 1976.

\section{GODSA (Comisión Laboral de).}

1. El tema de la encuesta, por su propia naturaleza, y sobre todo por la circunstancia española, ha de hacer que sus respuestas no sean teóricas o doctrinales, han de ser apreciaciones de lo que está ocurriendo o tiene trazas de suceder en relación con el sindicalismo español.

Se ha creado una Coordinadora de Organizaciones Sindicales fuera del sistema legal. No debe olvidarse, pese a que el confusionismo actual propicia el olvido, que existen otras organizaciones sindicales en potencia o actuando. La, hasta ahora única, Organización Sindical legal algún efectivo debe tener y también parece que han de contar los sectores católicos. Se puede pretender una organización sindical unitaria, pero no hay perspecti. vas de que esto sea una realidad inmediata. Podrá haber acuerdos o plataformas reivindicativas comunes, pero no creo que por el momento pueda conseguirse ni siquiera una actuación sindical unitarị.

La dualidad, unidad o pluralidad sindical no puede plantearse en términos abstractos. Se ha de reconocer el derecho de los trabajadores a elegir el 
modelo de organización sindical que consideren más adecuado a su ideología e intereses y ningún partido político está legitimado para imponer a los trabajadores una forma de organización sindical única. Esta afirmación no significa el desconocer los intentos que se dan en el movimiento sindical para conseguir la unidad sindical, pero, en todo caso, esta unidad ha de surgir de la base y tener su fundamento en la libre aceptación de los trabajadores.

2. La libertad sindical representa algo más que reconocer juridicamente a organizaciones sindicales hasta ese momento existentes. La libertad sin. dical representa el reconocimiento social de que existen organizaciones de trabajadores con capacidad para defender sus intereses y frente a las cuales al Estado, garante supremo de la convivencia social, le corresponde la fundamental misión de mantener las condiciones objetivas que permitan realizar sus fines sindicales. No hay libertad sindical sin que los sindicatos, en sus formulaciones de organización, funcionales y operativas, no respondan a los principios democráticos. La libertad sindical pasa por la democracia politica. Sin democracia es vano hablar de libertad sindical. No se rrata de establecer limites y requisitos legales o administrativos para el desenvolvimiento de la actividad sindical. Ha de ser la propia respon. sabilidad y su propio prestigio frente a los sindicados y la sociedad entera los que han de marcar los límites de las actuaciones y reivindicaciones de los sindicatos.

3. Distingamos entre acción sindical y movimiento obrero. Al Estado le interesa tener claro quién es su interlocutor válido y responsable. Lo que no es conveniente ni deseable, es la pugna entre organizaciones sindicales por la captación de sus afiliados, es el camino abierto a reivindicaciones desmesuradas y de imposible logro, a la demagogia, en definitiva. Esto no ocurre cuando se ha conseguido un reparto de influencia geográfico o sectorial, entre las diversas organizaciones sindicales, pero ello está lejos de ser realidad en la situación española. Las empresas están en medio de todas estas pugnas sindicales $y$, actuando inteligentemente, a los empresarios españoles también les interesa la actuación unitaria de las organizaciones sindicales.

Por otra parte, tal como está formulada la pregunta, hablar de actuación unitaria del movimiento obrero es meterse en otra cuestión que sólo en parte tiene que ver con el sindicalismo. Es aceptar un mito que hasta la fecha no ha sido realidad en ningún sitio, aunque todos hablemos de él. Lo que está claro es que la expresión "movimiento obrero" tiene unos alcances más políticos.

4 y 5. Sí que soy partidario de la independencia de las organizaciones sindicales de los partidos políticos. Lo que ocurre es que este deseo no tiene que ver nada con la realidad. Con repasar la realidad española y la de todos los países, basta. El hombre es trabajador y ciudadano a la vez. Las posibilidades de acción politica que ofrecen los sindicatos no se les han escapado nunca a los partidos, menos en los momentos de profundos cambios politicos. En el caso español la confusión es tal, que plantear esta cuestión de la separación entre sindicatos y partidos es, como ustedes indican, una cuestión de pura utopía.

6. Si la realidad es de confusión entre sindicatos y partidos políticos, lo más claro es manifestar y exponer esa realidad. Lo que no es lícito es estar pregonando que sólo se hace sindicalismo para descubrir, cuando con- 
viene a los intereses del partido al que realmente se sirve, que desde toda la vida se era militante de ese partido y que lo que se estaba haciendo era servirlo desde el liderazgo sindical.

7. Oue los sindicatos obreros actúan como grupo de presión ante los poderes públicos es una realidad. Lo que tiene gravedad es que se olviden, cuando su poder social se lo permite, que en un país se deben mantener otros intereses además de los que los sindicatos deben defender. La organización política de un país moderno ha de permitir la manifestación de todas las fuerzas sociales. En una sociedad pluralista se ha de reconocer la existencia de intereses contrapuestos y la posibilidad de su manifes. tación y defensa. Cuando sólo se deje oír alguno de estos intereses, imponiéndose sobre los demás, es clara señal de que algo va mal en esa sociedad.

8. Del pacto social se habla ahora mucho; yo creo que es algo más que un acuerdo entre el Gobierno y los sindicatos. Los sindicatos y los empresarios pueden acordar treguas en el planteamiento de reivindicaciones obreras, si los empresarios cumplen determinadas condiciones, pero creo que el pacto social hace referencia a cuestiones que trascienden de lo que es propio de las relaciones entre empresarios y trabajadores. Tácita o expresamente las sociedades se asientan en grandes pactos sobre las cuestiones que permiten la convivencia. En los momentos de cambio político estos pactos han de revisarse y establecerse nuevos compromisos entre los grupos y clases sociales. Las sociedades que actualizan de una o de otra

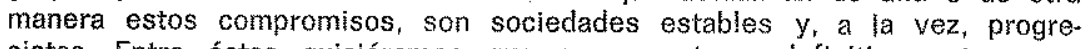
sistas. Entre éstas quisiéramos que se encontrara definitivamente nuestro país.

9. De mi respuesta anterior se deduce que no considero la existencia de una bipolaridad en el poder político compartido entre el Gobierno y los sindicatos. En la expresión del pacto social, entendido en el sentido amplio que he señalado en $\mathrm{mi}$ anterior respuesta, coinciden organizaciones sindi. cales, partidos políticos y otras representaciones sociales formales. Lo que no puede olvidarse es que el pacto social puede contenerse en medios que son tradicionales en los países occidentales; la reforma constitucional, o un Plan de Desarrollo, por ejemplo, pueden ser ocasión para que este Pacto Social se manifieste. $Y$ está claro que estas y parecidas ocasiones sólo pueden tener, para ser generalmente aceptadas, una formulación y concepción democrática.

10. Las utopías son para escribirlas. Algunas de ellas logran movilizar voluntades y producir grandes convulsiones sociales, pero no tienen como destino realizarse. Pueden imaginarse otros modelos de sociedad diferente a la que estamos viviendo, pero la consecución de los mismos sólo puede ser gradual. ¿Puede creerse seriamente que estamos ante una ocasión revolucionaria? Formamos, inevitablemente, parte de Occidente y nuestro sindicalismo podrá tener pecullaridades propias, pero no podrá separarse del modelo existente en estos paises.

11. Para que exista la democracia sindical, la representatividad sindical exige el ejercicio del derecho de los trabajadores para elegir a sus representantes. Esta representación democrática no termina con hecho de elegirlos; precisa de mecanismos de control, de manera que la base pueda, a distintos niveles, intervenir y controlar democráticamente la aco tuación de sus representantes previamente elegidos. La imposición de re- 
presentantes, el atribuirse representaciones de organizacions sindicales no controladas por métodos electorales democráticamente aceptados, evidencia la falta de democracia interna sindical. Si se llega a más y desde los cuam dros de una partido político es desde donde se dirige a un sindicato, estar mos ante una forma de totalitarismo, aunque la desfachatez llegue a pretender monopalizar la democracia y a considerarse con atribuciones para distribuir patentes de democracia.

12. El tema del actual patrimonio sindical conviene aclararlo seriamente y sensatamente. El patrimonio sindical se ha ido formando gracias a las llamadas cuota empresarial y cuota obrera, que teóricamente han aportado empresarios y trabajadores y con otras aportaciones, fondos públicos en su mayoría, destinadas, casi siempre, a las Obras Sindicales. Pero no se puede olvidar la incidencia de la cuota sindical en los costes de la mano de obra que han soportado las empresas en los años en que se ha formado el patrimonio sindical.

Como cualquier impuesto indirecto, ésta es la naturaleza económica de la cuota sindical, su importe ha repercutido en los precios de los bienes y servicios pagados por los consumidores. El patrimonio sindical ha sido posible por los mayores precios que todos hemos pagado. Es cierto que los trabajadores son consumidores; pero no hay que olvidar tampoco; primero, que no todos los trabajadores españoles han estado obligatoriamente sindicados; por ejemplo, funcionarios, trabajadores autónomos, y segundo, los empresarios y los profesionales de profesión liberal, también trabajan y también son consumidores. Sí que es cierto que la incidencia de los mayores precios ha repercutido de manera preferente sobre quienes, por sus menores rentas, se han visto forzados a dedicar todos o casi todos sus ingresos al consumo $y$ que esto ha sucedido con los trabajadores asalariados. Pero no hay duda alguna de que los bienes que integran el patrimonio sindical representan una forma de bienes públicos y su destino ha de ser consecuente con su naturaleza.

13. Las Obras Sindicales, teniendo diverso origen, han llegado a ser organismos que prestan verdaderos servicios sociales a los trabajadores, en algún caso pioneras de esta prestación en nuestro país. Estos servicios se prestan en régimen delegado de la Administración. Casi todas las Obras Sindicales tienen un paralelo en otro organismo de la Administración, Obra Sindical del Hogar en el Instituto Nacional de la Vivienda; Obra Sindical de Formación Profesional en el actual Servicio de Empleo y Acción Formativa del Ministerio de Trabajo, etc. La recuperación o la absorción de las funciones que estas Obras realizan por parte de los organismos de la Administración parece lo conveniente: ya existe el precedente de la Obra Sindical de Colocación, absorbida por el S.E.A.F. del Ministerio de Trabajo, y con ello de los bienes y personal a estas Obras Sindicales afectos.

14. El derecho a la huelga debe ser reconocido en nuestra legislación fundamental; la posibilidad de que un grupo de trabajadores se declare en huelga debe dejar de ser sólo un "recurso" reconocido legalmente cuando se ha agotado un complicado procedimiento y se cumplen unas condiciones demasiado restrictivas. Lo que no tiene clara justificación es contraponer derecho a la huelga con despido libre. Despido libre no existe realmente en ningún país occidental; en todos los paises occidentales si existe reconocido expresamente el derecho a la huelga, aunque se exijan para su ejercicio determinados requisitos. No deben confundirse instituciones de naturaleza jurídica tan diferenciada. El derecho de los trabaladores a declararse 
en huelga es un derecho colectivo; el despido, con unos u'otros aspectos, es una forma de terminar un contrato individual entre un empresario y un trabajador.

Pero también es yerdad que hoy se ha roto el equilibrio, y que se ha hecho en merma de la productividad y de la disciplina de las empresas. Un porcentaje razonable y efectivo de despido por estas causas es estrictamente necesario, si no hemos de acabar con el sistema de libre inicia tiva y responsabilidad empresarial.

Cuestión distinta es que sean las empresas, en el sistema de economía de mercado en el que nos desenvolvemos, las que tengan que cumplir funciones cuya realización son un claro compromiso social. Ante la escasez de puestos de trabajo, lo más sencillo es poner trabas a las empresas para despedir a su personal; pero las empresas no tienen como misión el realizar misiones que corresponden a un servicio nacional de empleo. Esto es una forma de desvirtuar las funciones propias de la empresa y de resque. brajar la necesaria eficacia empresarial. Compromiso social es que cada ciudadano viva de su trabajo, y si está en paro sea la comunidad social la que le ampare en este infortunio.

29 de septiembre de 1976.

HERMANDADES DEL TRABAJO (Un equipo cualificado de las). A título propio.

1. La unidad sindical no puede imponerse; seria el peor servicio que se hiciera al movimiento obrero. Sin embargo, es una tendencia que responde a una necesidad sentida a lo largo de su larga lucha.

Hoy la realidad del movimiento obrero se muestra plural; esto no impide que, a la par de su reconocimiento, se luche con el mayor interés en la culminación de un proceso unitario. Entretanto, el único camino viable se da en el seno de la empresa donde coinciden los intereses profesionales particulares y los generales de los trabajadores.

1 bis. La unidad sindical solo puede venir dada por la voluntad de los trabajadores. Esa voluntad hoy no es evidente.

La actuación unitaria, libre y sin mediatizaciones, es posible en la em. presa. A niveles superiores las influencias ideológicas dejan sentir su influencia y la servidumbre a pactos extralaborales.

2. Por cuestión de principio, avalado por la Doctrina Social da la lglosía y los acuerdos de la O.I.T., núm. 87 y 98.

3. En el num. 1 reconocíamos la pluralidad sindical como un hecho que se impone.

La unidad de acción, consecuencia de un acuerdo de los trabajadores, debatido y consentido, sólo puede obtenerse en las fábricas o empresas donde los intereses unitarios de base se imponen a los particularismos de las ideololas. 
4. Sí.

5. No es utopía; es muy difichl. La verdadera independencia puede darse según lo apuntado en el apartado 3.

6. Podría promulgarse una normativa legal e incluso, en el seno de las Organizaciones Profesionales, un comité de control o grupo censor que vigilara la autonomia en lo ideológico. En las Asambleas de base, participativas y corresponsables, donde se puede obtener la mayor garantia.

7. Si.

8. El pacto social siempre se impone. Lo que no es admisible, en los representantes obreros, es un espiritu "pactistan.

9. Sí, efectivamente, es una forma de ejercer poder, poder positivo que compense el excesivo del Estado y de los grupos económicos.

Las Organizaciones sindicales de los trabajadores no pueden estar ausentes de ese diálogo. La forma establecida de presencia podría ser a través de los propios mecanismos democráticos de participación politica.

Esta aparente contradicción con lo afirmado en los puntos 4 y 5 no significa una "integración" en su sistema, sino el diálogo que debe establecerse $\sin$ abandonar la perspectiva de clase que se representa.

10. Reivindicativos en to inmediato, revolucionario o transformador en sus finalidades. base a

Los rasgos fundamentales de una sociedad futura los concebimos en

- Una propiedad socializada.

- Una gestión comunitaria, participativa y responsable, en lo económico, social y político.

El sindicato puede ser el instrumento educador del "nuevo hombre", capaz de vivir esta sociedad, y a la vez ir creando las estructuras de autogobierno y las situaciones sociales que preparen, en libertad, dichos cambios.

Las leyes responderi a necesidades del cuerpo social; el sindicato puede ser el vehículo o cauce de estas necesidades y la palanca que fuerce la promulgación de leyes.

11. En la base.

12. El patrimonio sindical pertenece a todos los trabajadores que han cotizado. No se puede adjudicar más que a los trabajadores, en su con junto, para que sirva a sus intereses, necesidades y objetivos.

Cualquier fórmula que se arbitre tendrá que tener el carácter social que su origen y pertenencia acreditan.

13. Las que cumplan objetivos o funciones sociales se conservarán o potenciarán. Las inútiles o gravosas habria que eliminarlas. 
14. La huelga como "ultima ration de los trabajadores ha de estar contemplada en un marco juridico.

Los criterios restrictivos de la huelga y el despido no pueden ser los mismos, y su normativa jurídica tampoco.

La seguridad en el empleo es el único patrimonio que la sociedad puede oponer a los trabajadores 0 , en su defecto, la Seguridad Social. La huelga es el derecho que asiste a los trabajadores "a no trabajar" cuando el enfrentamiento de intereses bloquea el diálogo o la negociación de las condicio nes reivindicativas.

\section{IGLESIAS SELGAS, Carlos. Presidente del instituto de Estudios Sindicales.}

1. Aunque lo ideal sería una Organización Sindical unitaria voluntariam mente adoptada por los trabajadores, creo que la actual situación española lo más que consentirá será una actuación unitaria, mediante pactos en cada caso, dentro de un pluralismo organizativo.

El reconocimiento de la libertad de asociación sindical es algo que hay que dar por conseguido en España. Esta libertad de asociación permitirá el reconocimiento de las organizaciones de hecho existentes que, hoy por hoy, no parece factible se planteen el tema de su fusión en una organización sindical unitaria.

Lo que sí puede ocurrir es que los trabajadores, independientemente de las organizaciones que libremente creen, cuenten con estructuras de carácter oficial que faciliten la colaboración entre ellas para la realización de determinadas funciones de carácter público.

Al efecto, se podría contar con algunas de las estructuras unitarias exis. tentes con las necesarias adaptaciones. No creo que existan motivos de peso que obliguen a malbaratar los esfuerzos de muchos años.

2. Por cuestión de principio, ya que la libertad sindical es una manifestación de la libertad de asociación reconocida con carácter general en toda sociedad libre, y por criterios de acción política, en razón a que la situa. ción socio-política española exige el reconocimiento de la libertad sindical.

3. Varias son las fórmulas a través de las que podría compaginarse el pluralismo sindical con la conveniente actuación unitaria. De todas ellas existen precedentes en que podríamos inspirarnos. Una primera opción consistirá en que los directivos de las distintas centrales confederales u organizaciones de rama se pusieran periódicamente de acuerdo para colaborar. Esta es la fórmula que cuenta con más antecedentes en el sindicalismo comparado.

Una segunda opción sería la del sindicato más representativo, que, según es conocido, parte del reconocimiento de la facultad de crear asociaciones de modo espontáneo, pero establece que uno o varios entre los sindicatos existentes tienen en exclusiva el ejercicio de las funciones públicas de representación. 
Finalmente existe la solución de las Cámaras de Trabajadores, de las que existen algunos ejemplos en Austria, Luxemburgo y algunos Länder de la República Federal Alemana. Es algo parecido a lo que ocurre con los empresarios, que tienen las Cámaras de Comercio e Industria $y$, al mismo tiempo, asociaciones empresariales.

4. Pienso que tiene ventajas la separación entre las organizaciones pro. fesionales y las organ̆izaciones politicas. Sin embargo, en las organizaciones de trabajadores el problema presenta particular delicadeza en razón a que en éstas no sólo se plantean las reivindicaciones laborales, sino las transformaciones estructurales de la popia sociedad. En estas condiciones, el planteamiento sindical encierra en si opciones políticas que no se pueden eludir.

5. La independencia de las organizaciones sindicales respecto a los partidos políticos es conveniente. Es de sobra conocido el probiema que se plantea a aquellos partidos que obtienen el Poder principalmente por el voto obrero $y$, en el ejercicio del mismo, se ven obligados a adoptar medidas de gobierno, muchas de ellas contrarias a las exigencias de los obreros.

6. Como lo han hecho en otros paises, prohibiendo simultanear mandatos sindicales y mandatos políticos. Pero, insisto, no creo prácticamente posible-y menos on nuestras actuales circunstancias-una separación completa.

7. En toda sociedad moderna son muchos los grupos de presión que entran en juego, y es natural y obligado que los trabajadores cuenten con medios de defensa. No veo razón especial por la que se aplique un trato discriminatorio a las organizaciones de trabajadores.

8. El pacto social ha sido considerado por algunos como una panacea. Juzgo que en el momento económico que atravesamos sería muy conveniente. Ahora bien, también creo que no nos encontramos en condiciones de llegar a la suscripción de un pacto social.

9. El pacto social no es una cosa tan clara como parece desprenderse del texto de la pregunta. En realidad, el pacto social, tal como yo lo concibo, no es a dos, sino a tres, puesto que también entran en juego las organizaciones empresariales.

Obreros, empresarios y Estado pueden y de hecho tienen actitudes dis tintas. Por eso no me parece razonable que para la participación de los trabajadores haya de recurrirse exclusivamente a los mecanismos del sufragio que son distintos.

10. Son muchas las preguntas que formula en una misma.

El sindicalismo tiene que ser siempre, al menos en las sociedades neocapitalistas, reivindicativo y revolucionario. Esta es, por lo menos, la experiencia de los paises latinos, lo que no quiere decir, ni mucho menos, que no acepten a determinados efectos los supuestos de la sociedad en que actúa.

En cuanto a los rasgos fundamentales de la sociedad futura, es un tema de muy difícil contestación en el marco de una encuesta de carácter general como ésta. Sugiero a FOMENTO SOCIAL que dedique a este tema una encuesta especifica en su momento. 
11. El poder en el sindicato debe encontrarse siempre en la base, no es un partido paralelo. Otra cosa es que, por los mecanismos de todo sistema organizativo, tengan alguna participación en las decisiones más importantes altas instancias, que debe evitarse sean ajenas al propio sindicalismo.

12. Pienso que el patrimonio de la Organización Sindical Española debe seguir afecto a los trabajadores y a los empresarios como conjunto, a través de servicios sociales de carácter público y significación profesional.

En determinadas condiciones, algunas partes de este patrimonio podrán adscribirse a las asociaciones de trabajadores y de empresarios que libremente se creen. Pero lo que se ha creado con el esfuerzo de todos no debe quedar en manos de unos pocos. Así como tampoco "confiscarsen por el Estado.

13. Cada una de las obras sindicales deberá tener, a mi juicio, un trat tamiento distinto. Como es natural, y asi lo sostuve en mis libros, este tratamiento debe corresponder a las características de la respectiva función. Es este uno de los temas con que tendrá que enfrentarse el Gobierno y seguidamente las Cortes.

14. Tengo muchas dudas sobre la afirmación reiteradamente formulada por los medios empresariales de que el despido limitado y la huelga son incompatibles. La legislación y sobre todo la práctica de Derecho comparado no abundan en tal sentido. De todas maneras, este es un tema que está sobre el tapete y que en España se tendrá que abordar.

14 de octubre de 1976.

MUÑOZ CAMPOS, Juan. Ex Vicesecretario de Ordenación Económica de la C. N. S. de Madrid. Contesta a título personal.

1. De la Organización Sindical unitaria mejor es no volver a hablar. Al menos durante un buen periodo de tiempo, con el fin de poder decantar el conocimiento de los hechos e intentar saber si es que conceptualmente no es viable o, más bien, que todo se hizo mal.

Pienso que la actuación unitaria dentro de un pluralismo asociativo en inexcusable, si de veras se pretende que el sindicalismo desempeñe en la sociedad el papel que por su propia naturaleza le corresponde. Poner en pie, con la fecundidad a que debe aspirarse, al mundo del trabajo sólo será posible si se desarrolla eficazmente la libertad sindical y su práctica real y el ejercicio de la acción sindical se consumá en la unidad.

2. Habria que viabilizar, sin más demoras, el ejercicio de la libertad de asociación, facilitando que cuantos trabajadores y empresarios lo deseen puedan constituir organizaciones sindicales con las características que tipifica la O.I.T. Y ello por cuestión de principio. Y, asimismo, habría que estimular la práctica real de este derecho, para intentar cortar el fenómeno que puede lfamarse absentismo sindical.

3. El ejercicio de la libertad sindical y su posible conversión en realidad funa vez se cubran determinados requisitos, no de carácter constitutivo 
y sí de simple conocimiento y registro) no es incompatible con la actuación unitaria, en cuanto para ésta se dé vida a unos órganos con esa finalidad constituidos, gobernados con total autonomía, que actúen permanentemente por medio de representantes democráticamente elegidos, no permanentes (sî la función, nunca los hombres).

Pienso que sindicato y partido politico deben ser totalmente indepen. dientes, aunque operen sobre un mismo colectivo.

4. El movimiento sindical, aparte de su actividad reivindicadora, en to trascendente debe aspirar a lograr un nuevo modelo de sociedad y una empresa diferente, en la que el capital sea instrumento, y el trabajo, en su más amplia acepción, protagonista. $Y$ el desempeño de ese papel en la sociedad es compatible con cualquier ideología política de carácter democrático que no niegue viabilidad a un quehacer empeñado en la transformación superadora de la actual sociedad hacia otra en la que la paz y el orden seah̆ consecuencias de la justicia.

5. Si los partidos políticos y los sindicatos no logran la efectiva presencia de sus afiliados y quedan en manos de los lideres, la experiencia demuestra que la real independencia suele ser un camelo.

6. En la práctica puede salvaguardarse esa independencia mediante la declaración de las incompatibilidades reales, la sanción a sus inobservancias y especialmente: evitando el absentismo sindical, persuadiendo al trabajador de que debe ser el protagonista de sus propios destinos, convenciéndole de que no precisa intermediarios, empujándole a que se empeñe en su propia elevación intelectual, humana y materlal; logrando que las asociaciones sindicales funcionen continuadamente con la real presencia de sus hombres...

7. Realmente esos desmadres se producen cuando el sindicato obrero no tiene una idea clara de que la actuación sindical no puede quedarse en lo reivindicativo; cuando se le maneja, cuando, pese a que aparecen como grupos de presión, es instrumento de alguien para algo. El trabajador no manipulado no actúa jamás contra los intereses generales de su país ni de ninguno. Esto es una constante histórica. Cuando la manipulación se da...

8. Más que de pacto, yo hablaría de norma que fije cómo quede regis trado el nacimiento de las asociaciones sindicales; cómo han de funcionar los organos de acción unitaria; cuáles son los fines a alcanzar y los medios de que disponen.

$Y$, sobre todo, to que importa son las costumbres. En sentido amplio, naturalmente. Costumbres de actuación hacia una sociedad transformada, en la que, poco a poco, pero con mucha firmeza, se vayan clausurando las estructuras de poder detentadas por unas minorías, y se ponga a las mayoría en trance de asumir sus proplos quehaceres y pechar con sus responsabilidades, dotando a los hombres del trabajo de medios para atender su personal destino y hacer su vida trascendente.

9. Pienso que a unas metas superadoras cabe acceder sin bipolaridad de poderes, sin meter a los sindicatos en la politica o en las áreas de poder. Si hay estructuras sociales vivas, no precisan de poder político para su actuación positiva. En la elaboración de la norma han de contar los tra- 
bajadores, pues son tan ciudadanos como cualquier otro. $Y$ en la creación de costumbres, no digamos. En los sindicatos se integran, en cuanto miembros de un proceso productivo que hasta ahora los ha considerado como instrumento para producir y los ha manipulado como elementos para consumir. Por eso, trabajadores y sindicato han de dar vida a otras formas, otras maneras, otras costumbres, otros talantes. Han de actuar en la pluralidad de las asociaciones y en la unidad de la acción, sin permitir que ni uno solo quede fuera del movimiento sindical, para utilizar todos los medios de que puedan disponer, que son muchos si bien se piensa y se actúa con prudencla, pero con energía y tìno, para. lograr no sólo el reconocimiento de sus legitimos intereses, sino también la transformación de este sistema de producción que hoy padecemos en otro que se corresponda con la propia naturaleza del hombre, tanto productor como consumidor. Un sistema, en definitiva, que esté al servicio del hombre. $Y$ para llegar a él no hace falta tanto ser parte del poder como tener voluntad y unidad de actuación. En cuanto el sindicalismo constituya un verdadero tejido social, en el que todo hombre tenga su propia tarea, la desarrolle con pleno sentido de la participación y la asuma con responsabilidad, ya se cuidarán los políticos de andar en linea recta si, a través de uno u otro partido político, quieren de verdad tener los votos del mundo del trabajo.

10. Para mí, el sindicalismo es algo muy complejo y, en parte, el gran desconocido.

Claro está que mientras la empresa no llegue a tener un estatuto jurín dico concorde con la verdadera comunidad humena que verdaderamente es, en tanto no sea entendida como tal comunidad por quienes la integran y el capital se atribuya todo el poder de decisión y casi todos los beneficios (como también casi todos los riesgos), el sindicalismo ha de ser un instrumento reivindicativo para los trabajadores. Pero en este singular trance en que nos encontramos (a nivel mundial, siquiera aquí en España la situación puede ser calificada de crítica), los hombres que vemos con cierta responsabilidad el presente y que nos sentimos abocados al futuro hariamos mal, muy mal, en dejar al sindicalismo reducido a un mero papel reivindicativo, que en el fondo es un apoyo real al sistema capitalista. Sólo el sindicalismo ha demostrado, a través de una lucha continuada, algunas veces sangrienta, poseer fuerza y dinámica suficientes para enderezar algunos errores de la sociedad. Ahora ya, por su propia dinámica, debe ser puesto en el trance de intentar, si efectivamente en él se integran todos cuantos trabajan, dar a la vida de estos hombres que trabajan (al menos a ellos) un sentido tras. cendente que les impulse a combatir, mediante la acción sindical, contra la filosofía básica del capitalismo, contra la economía fundada en el provecho de algunos, contra la explotación de las multitudes, contra la degradación del hombre como trabajador y manipulado como consumidor. Sólo un sindicalismo que viva en la libertad y actúe en la unidad puede ser instrumento apto para desarrollar esas tareas. $Y$ también la de transformar la empresa, haciéndola en lo económico más congruente con los elementos que la componen, y en lo social, una verdadera comunidad en la que la generación de injusticias quede sustituida por la paz, fruto de la justicia,

11. El poder de decisión debe estar en los trabajadores. A través de las elecciones para la designación de sus representantes y a través de la asamblea para la toma de decisiones. Siempre mediante el voto secreto. Todas las decisiones a nivel de empresa deben ser tomadas por los propios trabajadores, en votaciones secretas y ejectitadas por sus propios representantes de empresa elegidos por votación sacreta, sin la presencia de ninguna asociación sindical. 
A nivel local, cada trabajador se incorpora a la asociación que más le guste, o promueve otra. En todo caso, los trabajadores no sindicados voluntariamente quedarán automáticamente incorporados al centro de trabajadores no sindicados, del que podrán darse de baja en cualquier momento para ser alta en una asociación sindical. Claro que tal entraña la obligatoriedad sindical; pero bien distinta de la que hemos padecido: obligada la sindicación, con toda libertad para elegir sindicato y aun para crearlo.

Cabrá constituir federaciones y confederaciones a nivel provincial, en la forma y modo que libremente convengan los rectores de las respectivas asociaciones. $Y$, asimismo, a nivel nacional. A este mismo nivel se constituirá la Unión Nacional de Sindicatos de Trabajadores (con éste u otro nombre), con el carácter de congreso abierto permanentemente, con representación de cada una de las confederaciones o federaciones en proporción con el número de afiliados que cada una tenga, y con una dirección colegiada y rotativa en la que no quepan las reelecciones.

Pienso que así se puede cortar el absentismo sindical, tan evidente en el área occidental, acabar con la atomización de los trabajadores, evitar la dictadura de las mayorias e impedir la profesión de líder sindical (quien la empieza acaba, más bien pronto, en galápago).

Hasta podria llegarse a la cuota sindical obligatoria, recaudada por Hacienda o por el I.N.P., cuyo importe revertirá íntegro a las entidades sindicales en proporción a sus afillados. Naturalmente que se trata de un esquema a desarrollarse tras de mucho pensar por los propios interesados y por sus respectivos representantes democráticamente elegidos.

En definitiva, de la base, que es la empresa, a la cúspide, que puede ser la Confederación de ámbito nacional, ha de constituirse el sindicalismo sobre un amplio tejido, en el que el trabajador esté desempeñando, por sí mismo (sus representantes a todos los niveles serán mandatarios de ejecución) las tareas de designar esos representantes, fijar los objetivos de trabajo de todo ese pueblo. los métodos para alcanzarlos, etc., etc.; pero, insisto, sin delegaciones permanentes, ni temporales, en cuanto al quehacer y rehacer continuados, y sí sólo para ejecuciones concretas o actuaciones especificas, bien precisadas y claramente determinadas.

En definitiva, se trata de que el sindicalismo sea un movimiento renovado, continuado, que no descanse nunca en los líderes, los tecnócratas - los burócratas, y sí en los propios trabajadores, cada vez más capaces, más competentes, más actuantes, más integrados...

12. Ese patrimonio es del mundo del trabajo, por lo que hay que estudiar bien a fondo cómo se le atribuye. A mi modo de ver, deberían ser los propios sindicatos quienes en su día resolvieran, cuando hubieran logrado que el sindicalismo madurara.

13. Las obras sindicales habrán, en general, de continuar cumpllendo sus funciones, mejorándolas, naturalmente. Eso sí, administradas por técnicos competentes en cada materia; pero bajo la rectoría de los trabajadores mediante órganos de gobierno, democráticamente elegidos y realmente representativos de las diferentes asociaciones sindicales.

14. Esa normativa a la que la pregunta se refiere, pese a que realmente pueda pretender la estabilidad en el empleo, no genera beneficios a los 
trabajadores, aunque algunos de ellos, individualmente, puedan sentirse muy satisfechos por las seguridades que les dispensa para actuar en discordancia con sus deberes.

El pleno funcionamiento del movimiento sindical ha de generar las bases de una normativa entre empresario y trabajador más concorde con la realidad, y en el futuro, esa tipificación jurídica de la empresa, que tan precisa resulta para lograr que los trabajadores queden integrados en ella y a través de ella en la sociedad.

22 de septiembre de 1976.

ZACUKRRE, Manuel. Membro del Secretariado Permanente y del Comite Eje. cutivo de la Unión Sindical Obrera (U. S. O.). Conteste reflejando de hecho las ideas de ese grupo sindical.

1. Nosotros somos partidarios de la unidad sindical. Es un principio irrenunciable de la U.S.O., recogido en nuestra Carta Fundacional, que data de 1961 .

El porcué de esa afirmación es muy sencillo: 1) Porque la unidad es el arma más eficaz en manos de los trabajadores para imponer sus reivindicaciones de clase. 2) Porque en nuestra perspectiva de transformación socialista de la sociedad es necesario, a través de la lucha sindical, ir con* quistando una relación de fuerzas favorable a los trabajadores como vanguardia de la lucha socialista hoy y como protagonistas directos de la sociedad socialista y autogestionaria mañana.

En esa perspectiva, la unidad sindical, la unidad de clase, es un factor fundamental. Nosotros propugnamos la unidad de acción ya-ahí está la C.O.S.-que se orienta a la conquista de la libertad y la democracia para construir en ese marco la unidad sindical.

2. Si; libertad de asociación sindical ya mismo. Sencillamente, por cuestión de principio. En cuanto a criterios de acción, somos partidarios de que en la libertad sindical se cree un marco unitario, un frente sindical de clase, que impida la atomización sindical, constituya una referencia de sindicalismo democrático y de clase para los trabajadores y sea capaz de impulsar realmente el proceso unitario.

No hay contradicción entre estas dos posiciones. Con la misma fuerza defenderemos la libertad sindical para todos, combatiremos el divisionismo y la atomización sindical, venga de la derecha o de la izquierda, es decir, de la C.N.S. o de ciertos grupos de CC.OO.

3. Con la unidad de acción, repito, y con un proceso de acción y discusión que vaya apuntalando conquistas unitarias a nivel de empresa, de rama, de sector, etc. Ese es el camino.

4. Por supuesto. Para la U.S.O., la autonomía sindical es parte esencial del tipo de sindicalismo que propugnamos. Los sindicatos dependientes de partidos políticos están incapacitados para llevar adelante una estrategia 
de clase, al estar subordinada su línea y su dinámica a los intereses del partido o los partidos. Por esa razón, la U.S.O. propugna y aplica escrupulosamente la autonomía sindical, que no supone el apoliticismo, sino la afirmación de que el sindicato debe elaborar su propia estrategia y perspectiva de acción a partir de la función reivindicativa que le es propia. Además, para evitar cualquier equívoco o problema respecto a la autonomía del sindicato, somos partidarios a ultranza de aplicar las incompatibilidades entre cargos sindicales y politicos a niveles superiores a la empresa, to cual no quiere decir que la U.S.O. no acepte la doble militancia de sus afiliados; lo que no acepta es que sus dirigentes lo sean a la vez de un partido, o viceversa.

La autonomía se complementa, además, con la aconfesionalidad del sindicato y su independencia respecto a cualquier entidad del tipo que sea.

Finalmente, la autonomia sindical es un concepto politico que busca afirmar la autonomía de la clase trabajadora y su protagonismo social y político al margen de cualquier injerencia o influencia externa.

5. De utopía, nada. La U.S.O. tiene ya casi veinte años de vida, de experiencia, de lucha, y es un modelo tangible de qué es y cómo opera la autonomía sindical. $Y$ no somos un caso aislado. En Europa, el nuevo sindin calismo, que representa en Francia la C.F.D.T. y en talia las Federaciones Unitarias del Metal, la Química, la Construcción, etc., se basa en el logro y. la práctica de la autonomía y las incompatibilidades.

Además, el camino de la unidad sindical pasa por la conquista y el ejercicio de la autonomía de las distintas fuerzas que concurren a ella y sí ese requisito falta, no habrá unidad sindical; puede haber, como mucho, acuerdos por arriba entre los grupos politicos que influyan o controlen los sindicatos.

6. Considero respondida la pregunta al referime anteriormente a las incompatibilidades entre cargos sindicales y políticos. Diré más: la autonomía o independencia del sindicato se sustenta en su propia capacidad de análisis, de elaboración de línea reivindicativa y política, y eso supone, a la vez, una gran preparación de sus cuadros, militantes y afiliados, que sólo la formación sindical basada en la profundización de la acción puede prom porcionarles. La autonomía sindical no es un prurito, es una conquista difícil que se renueva cada día y que no basta con quererla, hay que esforzarse por conseguirla y mantenerla a toda costa a partir de algo tan elemental, además de todo lo dicho, de la autofinanciación, difícil tarea en una situación de clandestinidad como la que nos tocó vivir desde nuestro nacimiento.

7. Si; efectivamente, cuando los sindicatos obreros adquieren poder, se configura en la sociedad un poder obrero. Eso es bueno. En tal caso no puede hablarse peyorativamente de un "grupo de presión", dadas las connotaciones negativas que tiene el concepto. Por supuesto, un poder obrero está para presionar al poder opuesto hasta transformar las hegemonías sociales y el modelo de sociedad capitalista. Pero no es correcto hablar de un "grupo de presión", pues cuando los sindicatos obreros son fuertes por activa o por pasiva, representan los intereses y las aspiraciones de la mayoría, cuantitativa y cualitativa, de la sociedad-la población asalariada-, y en este caso no puede establecerse la comparación con los típicos grupos de presión financieros, políticos, religiosos, etc. Estos últimos son 
siempre núcleos reducidos, aunque poderosos, de intereses; los sindicatos expresan los intereses de la mayoría de la población y, por lo tanto, los intereses generales de una nación.

8. No, nunca. En nuestra perspectiva el "pacto social" queda excluido, salvo en el caso de que los trabajadores lo determinen libremente.

Estamos hoy por un pacto político para instaurar la libertad sindical y la democracia en nuestro país, para normalizar la situación económica, no a costa de los intereses obreros, sino para asegurar a los trabajadores y al pueblo el bienestar y la capacidad adquisitiva. A partir de ahi, nosotros entendemos las relaciones obrero-patronales sobre una dialéctica de lucha y negociación que vaya afirmando el protagonismo social de los trabaja dores con vistas a una transformación progresiva y radical de las estructuras socio-económicas, políticas, cutturales, etc., de la sociedad capitalista.

En consecuencia, para nosotros el "pacto social" sólo beneficia al patronato, es el triunfo y el reconocimiento de su hegemonia política. Además, el "pacto social" en un contexto como el nuestro es un elemento de estancamiento. En una sociedad como la nuestra, las tensiones que generan las fuertes desigualdades, el poder de los monopolios y de la oligarquia más antisocial de Europa, no se puede pactar; se tienen que afrontar, luchar contra ellas y encontrar salidas negociadas ventajosas a los trabajadores y capas populares, hasta que un cambio en profundidad y de orientación socialista supere esas tensiones o las atenúe considerablemente.

9. En primer lugar quiero aclarar que un pacto social no es sólo un asunto entre gobierno y sindicatos obreros. Interviene siempre un tercer elemento decisivo: la patronal organizada.

Aclarado esto, sobre la segunda pregunta de este punto 9 opino que los sindicatos obreros no deben participar como tales en los, textualmente, "mecanismos democráticos de elección politica". Los sindicatos deben urgir a los partidos, al Estado y a la sociedad los objetivos y aspiraciones de su propia politica sindical (política salarial, de condiciones de trabajo, reforma fiscal, legislación laboral, política de inversiones, desarrollo regional armonizado, política de vivienda, de enseñanza, sanitaria, etc., ensancham miento de las libertades, etc., etc.). A nuestro modo de ver, los sindicatos de clase hacen su política de transformación social a partir de la lucha por mejorar permanentemente, hasta cambiar, la condición obrera en el sistema capitalista. Además, en el sindicato suele haber distintas opciones politicas entre sus miembros, y el sindicato como tal no puede decantarse por ninguna, sino tener la stya propia y en base a los principios anteriores.

Por lo tanto, no somos partidarios de encardinar los sindicatos al organigrama politico de poder. Máxime en un país como el nuestro, que arrastra cuarenta años de familla, municipio y sindicato como formas corporativas de "representación".

10. Como he ido expresando a lo largo de lo que va de encuesta, concibo el sindicalismo como un instrumento de los trabajadores para, a partir de la lucha permanente por la mejora de las condiciones generales de la población asalariada, instaurar una: nueva sociedad basada en: la propledad social de los medios de producción y de cambio, la descentralización del poder, el federalismo político, el desarrollo regional equilibrado e igualitario y la autogestión en los diversos planos de la vida social, económica y política. 
Nosotros llamamos a ese modelo de sociedad la democracia socialista o el socialismo autogestionario, que es la superación de la social-democracia y del socialismo leninista.

11. El poder tiene que estar en la base sindical siempre. Somos totalmente contrarios a que la politica sindical se elabore en instancias de partido. Por eso practicamos y propugnamos la autonomía sindical y las incompatibilidades de cargos sindicales y politicos a niveles superiores.

E porqué está muy claro. Si aceptamos que la orientación política se la dé el partido al sindicato, estamos aceptando el principio de la "correa de transmisión", estamos reduciendo y limitando el papel del sindicato, estamos manipulando su democracia interna y, lo que es más grave, estamos propiciando el que el sindicato quede prendido a una determinada política, que muchas veces puede ser contraria a los intereses específicos de los trabajadores.

Autonomía sindical e incompatibilidades son condiciones "sine qua non" para que las relaciones partido-sindicato se den a pie de igualdad y participen en esa confrontación todos los afiliados al sindicato, no sólo unos pocos dirigentes o militantes que lo son a la vez del partido.

12. El patrimonio de la C.N.S. tiene que ser restituido a los trabajadores españoles, pues ellos son sus legitimos dueños. El cómo restituir ese patrimonio estamos dispuestos a negociarlo con un gobierno demo. crático. -

13. Hay mucho de artilugio, de burocracia, de servicios fantasmas que no sirven para nada más que para justificar buenas nóminas y buenos "chollos".

En un futuro democrático, muchas de esas funciones asistenciales de la C.N.S.-típicas de un organismo corporativo-serán absorbidas por el sindicalismo democrático, en unos casos y funciones; por el Ministerio de Trabajo, de la Vivienda, de Agricultura, etc., en otros casos. Esa puede ser la fórmula para dar una solución al problema de los funcionarios sindicales a partir de su función actual en la C.N.S.

Lo que está claro es que en el futuro esos "servicios" es bien fácil reinsertarlos en una Administración del Estado democrática. Eso no es un problema que pueda justificar la no disolución de la C.N.S., que es la cantllena que hemos oído últimamente.

14. Qulero aclarar, en primer término, que la actual legislación sobre el despido no es restrictiva para los patronos, no lo ha sido nunca. En todo caso, cabe decir que en España el despido no ha sido gratis, pero si ha sido libre y no muy caro. $Y$ después de las medidas decretadas por el Gobierno el 8 de octubre, han quedado resueltas las inquietudes patronales sobre el tema.

Respecto a la segunda pregunta de este punto 10 , afirmo que los sindicatos obreros luchamos por el derecho a ta huelga y la utilizaremos siempre como forma de presión civilizada para asegurar otro derecho fundamental: el del trabajo y la supresión del despido libre. 
Un sindicato que acepte la contrapartida del despido libre al derecho de huelga, está aceptando el pensamiento liberal-burgués más trasnochado y, desde luego; no es un sindicato de clase. Para nosotros, el derecho a la huelga $y$ el derecho al trabajo son simultáneos y no permitiremos que se escamotee ni el uno $\mathrm{ni}$ el otro. $\mathrm{Ni}$ tampoco el negociar. o conseguir uno a costa del otro.

15 de octubre de 1976

\section{ZAPICO RODPIGUEZ, Noel Presidente del Consejo Nacional de Trabajadores. Contesta reflejando de hecho las ideas del mismo Consejo Nacional de Trabajadores.}

1. De poder escoger entre ambas opciones eligiría la segunda. La razón es evidente: al admitir como principio incuestionable la libertad sindical, creo que únicamente puede garantizarse este principio con la segunda de las opciones. Y entiendo que la acción del Movimiento Obrero debe ir hacia esta fórmula de respeto a las diferencias existentes en la clase trabajadora.

2. Tajantemente contesto que por cuestión de principio.

3. A través del pacto, sin exclusión alguna, de las diferentes Centrales que, democráticamente y con este carácter, aparezcan en el Movimiento Obrero. Principlos básicos de este pacto: respecto a las minorías, garantía de que las decisiones son democráticas; compromiso an el cumplimiento de las condiciones, y seguridad de que tales actitudes son aceptadas por la base 0 , en otras palabras, participación de la base en la formulación y compromisos del pacto.

4. Decididamente partidario.

5. Utopia absoluta, no; pero entiendo que, en efecto, la influencia de la ideologia mantenida y la política determinada por un partido influyen de una manera decisiva en la actuación de sus miembros afiliados, a su vez, a una Central.

6. Creo que puede haber dos caminos: uno, el que no coincidan en las mismas personas cargos de la alta dirección del partido y de la central; dos, no obligando a afiliarse a un partido determinado a todos los miembros de una Central, y garantizando el que democráticamente puedan asumir esos cargos personas que no son del partido.

7. ¿En qué manera no coinciden los intereses de la clase trabajadora con los del pais? ¿No puede ocurrir que cuando se habla de intereses del pais éstos estén identificados con una determinada situación privilegiada o con determinados intereses que no se identifican con los del pueblo? Creo que la actuación de los sindicatos obreros en defensa de los intereses de quienes representan, dados los mecanismos del sistema capitalista, encuentran factores correctores en favor de los intereses de otras clases. Por lo tanto, la exigencia de presión es connatural a la propia dialéctica capitalista.

8. Absolutamente necesario. Aunque entiendo debe añadirse a las organizaciones patronales. 
9. A pesar de las dificultades que entraña, siempre he defendido la participación sindical en los mecanismos democráticos. Me refiero a dificultades de tipo técnico en el orden del Derecho constitucional y en la técnica electoral. Creo que es un problema a resolver, porque las experiencias de la democracia inorgánica no han ido por esa vía. Pero advierto que al no tener mayoría parlamentaria, los sindicatos no van a obtener sus objetivos, y entiendo que la base no va a comprometerse en las responsabilidades de quienes les representan minoritariamente. La necesidad de garantizar que se pronuncien los trabajadores en las Cámaras legislativas, ha de compatibilizarse con la libertad de acción de la clase trabajadora, como colectivo autónomo en el contexto de los diversos colectivos que for. man la sociedad. En fin, el carácter reivindicazivo del sindicalismo no encontrará control por muchos controles institucionales que se le impongan.

10. Comprendo al sindicalismo como reivindicativo y revolucionario. Reim vindicativo para luchar por la defensa inmediata y a corto plazo de los intereses profesionales, económicos, sociales y culturales de los trabajadores. Revolucionario a largo plazo, con el objetivo de la transformación de las estructuras socio-económicas que impiden el desarrollo del hombre en todos sus aspectos, provocan desequilibrios de clase y territoriales, y condenan al pueblo a una situación de dependencia total de otros grupos minoritarios. El sindicalismo exige la promoción, como liberación de la clase trá. bajadora en su coniunto, no individualmente. Exige una sociedad con democracia formal, económica y cultural.

11. Ha de estar en la base, porque de no ser así no será un sindicalismo democrático, sino aparentemente libre e independiente. Si queremos unos sindicatos libres e independientes, la participación de la base es un principio indeclinable. La soberania de la base es fundamental, Lo que no quiere decir que la base no se decida por un partido...

12. El actual patrimonio de la Organización Sindical es de la clase trabajadora. Entiendo que el Estado debe garantizar: primero, que los trabaja dores lo sigan disfrutando; segundo, que los trabajadores participen directamente en su gestión; tercero, que las Centrales Sindicales actúen on esa gestión en representación de sus afiliados.

13. Al hilo de lo anteriormente expuesto, tales Obras y Servicios deberán mantener una organización común, es decir, formar un organismo autónomo que facilite y garantice la realización de los presupuestos que antes he señalado. Insisto, el patrimonio ha de ser un patrimonio del trabajador, autónomo para que efectivamente revierta su servicio en beneficio de todos los trabajadores.

14. Creo que el primer paso para llegar a una solución aceptable y justa es que se modifique el derecho de huelga de acuerdo con las exigencias de los trabajadores. Y en la medida que se establezca este derecho, así se podrá discutir el derecho al despido libre. Pero, y esto es importante, entendiendo que el despido libre no puede ser un derecho de los empresarios, sino una consecuencia de determinadas situaciones. Yo quisiera hacer también una pregunta: ¿es que se puede, socialmente y en justicia, hablar de despido libre con un paro como el actual y el que nos amenaza? ¿Es esto social, sin garantizar un seguro de desempleo justo? Parece que siempre son culpables del fracaso económico los trabajadores. ¿Se podrá despedir a los empresarios incapaces? No es demagogia. Cabe la solución de la 
autogestion por los trabajadores. Habrá que solucionar problemas más graves que el del despido libre antes de enfrentarse con esta opción. Como el del desempleo... ¿Se ha pensado también en la reacción de la clase tra. bajadora ante los despidos masivos? ¿Cuánto van a costarle a los empresarios las huelgas de solidaridad por compañeros despedidos? El despido libre no es un derecho, es una necesidad del sistema capitalista. Pero el derecho al trabajo es un derecho sagrado... Conviene que quienes lo preconizan reflexionen sobre las consecuencias de situaciones límites, amparadas por el Estado, pero que dejan a la clase trabajadora en un supuesto dialéctico brutal, inhumano, irracional e injusto: la situación de la necesidad, del hambre o de la escasez cuando se establece lo superfluo como necesidad en algunos grupos de la sociedad y cuando esa necesidad superflua se satisface con las plusvalías que exige el despido de trabajadores... A situaciones límites, soluciones límites, como, por ejemplo: la socialización de las industrias básicas. Lo señalo como un toque de atención de lo que puede correr por la mente concienclada de la clase trabajadora, y sobre todo de un sindicalismo de base en constante tensión relvindicativa ante las arcaicas estructuras socioeconómicas de un determinado país como es el nuestro.

28 de septiembre de 1976. 